\title{
君津製鐵所におけるダストリサイクル技術
}

\section{Dust recycling technology in Kimitsu Works}

\author{
織田博 史* ・茨城哲 治* \\ Hiroshi ODA and Tetsuharu IBARAKI
}

(Received January 21, 2008)

\begin{abstract}
Dust recycling technology by the rotary hearth furnace has been applied at Nippon Steel's Kimitsu Works since 2000. The dust and sludge with iron oxide and carbon are agglomerated into shaped articles and the iron oxide is reduced in a high temperature atmosphere. Zinc and other impurities in the dust and sludge are expelled and exhausted into off gas. The DRI pellets made from the dust and sludge have $70 \%$ metallization and are strong enough for being recycled to the blast furnaces.

No.1 plant, which was constructed in May 2000 and has an agglomeration method of pelletizing, recycles mainly dry dusts. No.2 plant, which was constructed in December 2002 and has an agglomeration method of extrusion, recycles mainly sludge. The combination of the two plants is a solution for recycling various kinds of dusts and sludge emitted in a large scale steel works as Kimitsu Works
\end{abstract}

Key Words: Dust Recycling, Rotary Hearth Furnace, DRI Pellets

\section{1. 緒 言}

君津製鐵所においては、以前より所内で発生する鉄分含 有ダストの多くを焼結等で再利用しているが、高炉での亜 鉛装入量制約等により発生ダストを全量再利用することは 困難であり、相当量の余剰ダストについて埋め立て等の処 分を行っていた。

ダスト中の主要成分は鉄分及び炭素分であり、これら資 源のリサイクル活用は投棄量削減、資源有効活用、省エネ ルギーといった近年の循環型社会形成推進の観点からも極 めて重要な課題であった。そこで、ダストの脱覀鉛処理に よる再資源化のためのプロセス開発及び実用化を推進して きた。この結果、回転炉床炉（RHF）を応用したダスト還 元処理プロセスにより高品質な高炉原料を製造する、ダス 卜の再資源化技術を世界で始めて開発した ${ }^{1,2)}$ 。

その後さらに、従来技術面、経済面にて処理の困難であっ た高水分スラジ類について、RHF で直接処理する、これも 世界初の事前処理技術を開発した ${ }^{3)}$ 。これにより、製鉄所 内で発生するほとんど全ての鉄系ダスト・スラジ類の高炉 原料としての再資源化が可能となった ${ }^{4)}$ 。

今回、これら RHFによる乾式および湿式処理を組み合わ せた最適なダスト・スラジ処理技術について述べる。

\section{2. 君津製鐵所の従来のダスト処理課題}

所内で発生する鉄分含有ダストは、以前より可能な限り 焼結原料あるいはコールドペレット原料として再利用して おり、高炬への再資源化を図っている。一方、高炉におい ては、高炉に装入されるトータル亜鉛量が増加すると、高 炉炉内において、亜鉛の付着物が生成し、高炉操業に支障 を来たすという問題があるため、原料中の亜鉛装入量制限 を設けている。

焼結あるいはコールドペレット・プロセスにおいては、 原料中の亜鉛がほぼそのまま製品に残るため、前記の高炉 への亜鉛装入量制約により、高亜鉛含有ダストを原料とし て使用できず、投棄に回されていた (Fig. 1)。

亜鉛制約による余剩ダストの総量は年間約 30 万トンに上 り、この中に含まれる鉄分約 15 万トン、炭素分約 3 万トン 相当が無駄な資源となっていた。

今回、前述の RHF を応用したダストリサイクル設備の実 機化により、従来投棄に回っていたダスト中の亜鉛を除去 することで、ほほ全銘柄のダスト・スラジ類を再資源化す ることが可能となった (Fig. 2)。

\section{3. 基本プロセスの検討}

今回のダスト類再資源化に必要なプロセス機能は前述の 通り脱亜鉛であり、脱亜鉛率としては全体ダストバランス

* 新日本製鐵株式会社君津製鐵所（广 299-1141 千葉県君津市君津 1)

Nippon Steel Corporation Kimitsu Works (1 Kimitsu, Kimitsu-City, Ciba 299-1141 Japan) 
から $90 \%$ 程度の能力が必要であった。還元脱覀鉛処理の可 能な種々の既存プロセスの中で、処理能力、脱亜鉛率、設 備費、ランニングコスト等を考慮し、今回のダスト処理に 最適なプロセスとしてRHF を選定した（Table 1)。

ダストの製鉄原料としての再資源化には使用先において 制約条件がある。再使用先として高炉、転炉、電気炉等が 挙げられるが、高炉使用においては低い亜鉛含有率と強度、

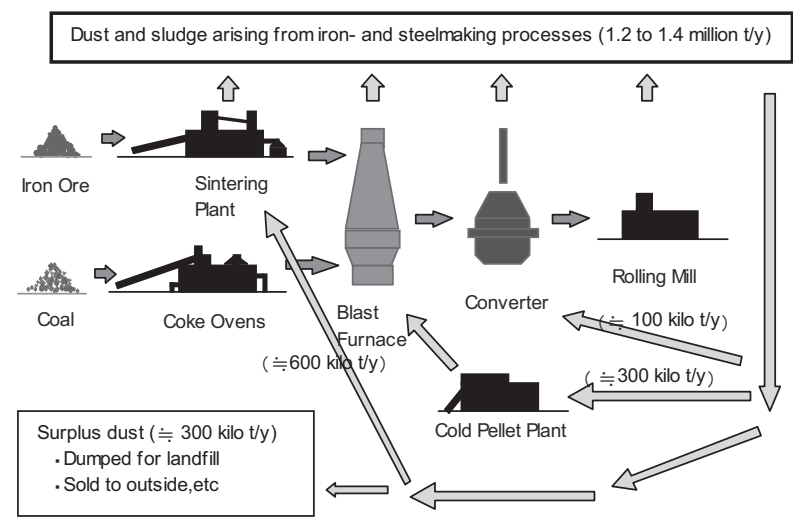

Fig. 1 Dust balance before construction of dust recycling plants

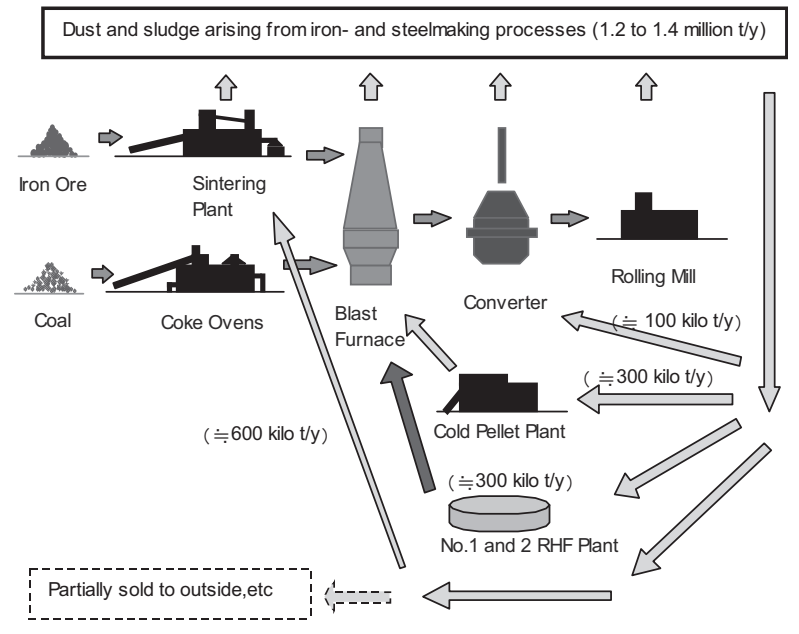

Fig. 2 Dust balance after construction of dust recycling plants
また転炉、電気炉での使用では、硫黄の含有率や金属化率 が大きなポイントとなっている。

君津製鐵所においては、RHF を応用することにより、低 亜鉛含有率で後述の高強度還元ペレットを製造する技術の 開発により、高炉への再資源化が可能となったことで、硫 黄除去や高金属化を行うことなく、経済的にダストを再資 源化することを可能とした。

\section{4. 今回開発したダストリサイクル技術}

\subsection{RHF 炉内の処理概要}

RHF による炉内でのペレットの還元について Fig. 3 に示 す。

装入装置から投入した原料ペレットは、炉床の回転進行 に従って加熱され、還元ゾーンにて $1100^{\circ} \mathrm{C}$ 以上の反応温度 に達し、酸化亜鉛や酸化鉄の含有炭素による還元反応が進 行する。ここで、亜鉛は気化しペレットから分離すること で、脱亜鉛反応が進行する。また、余㮃の CO ガスは 2 次 燃焼により熱エネルギーとして活用される。燃焼および反 応ガスは炉床進行に対し対向流となって、排ガス系へと流 れる。

還元されたペレットは排出装置にて炉外に排出され、 クーラにて冷却し、高炉へと輸送する。

\section{2 高強度還元製品製造技術の開発}

還元ペレット製品の高炉での直接使用においては、前述 の通り高炉原料として具備すべき品質を確保する必要があ る。特に炭材内装ペレットが強度発現し難いという従来知 見に対し、今回の還元製品の強度発現が可能か否かの事前

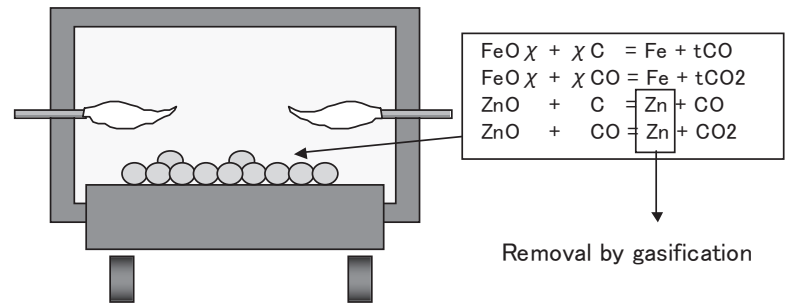

Fig. 3 Removal of zinc in rotary hearth

Table 1 Comparison of dust processing processes

\begin{tabular}{|c|c|c|c|c|c|}
\hline & $\begin{array}{c}\text { Rotary hearth furnace } \\
\text { (RHF) }\end{array}$ & Waelz kiln & Smelting type kiln & Electric furnace & Shaft furnace \\
\hline De-zinc ratio & $90-97 \%$ & $75-90 \%$ & $99 \%$ & $99 \%$ & $99 \%$ \\
\hline Designed maximum treatment capacity & $400,000-500,000 t / y$ & $80,000 t / y$ & $60,000 t / y$ & $30,000-50,000 t / y$ & $50,000-80,000 t / y$ \\
\hline Equipment cost & Low & Middle & Middle & High & Middle \\
\hline Running cost & Low & Middle & Middle & High & High \\
\hline Overall evaluation & O & $\triangle$ & $\triangle$ & $\Delta$ & $\triangle$ \\
\hline
\end{tabular}

※elative value when the RHF is 1 


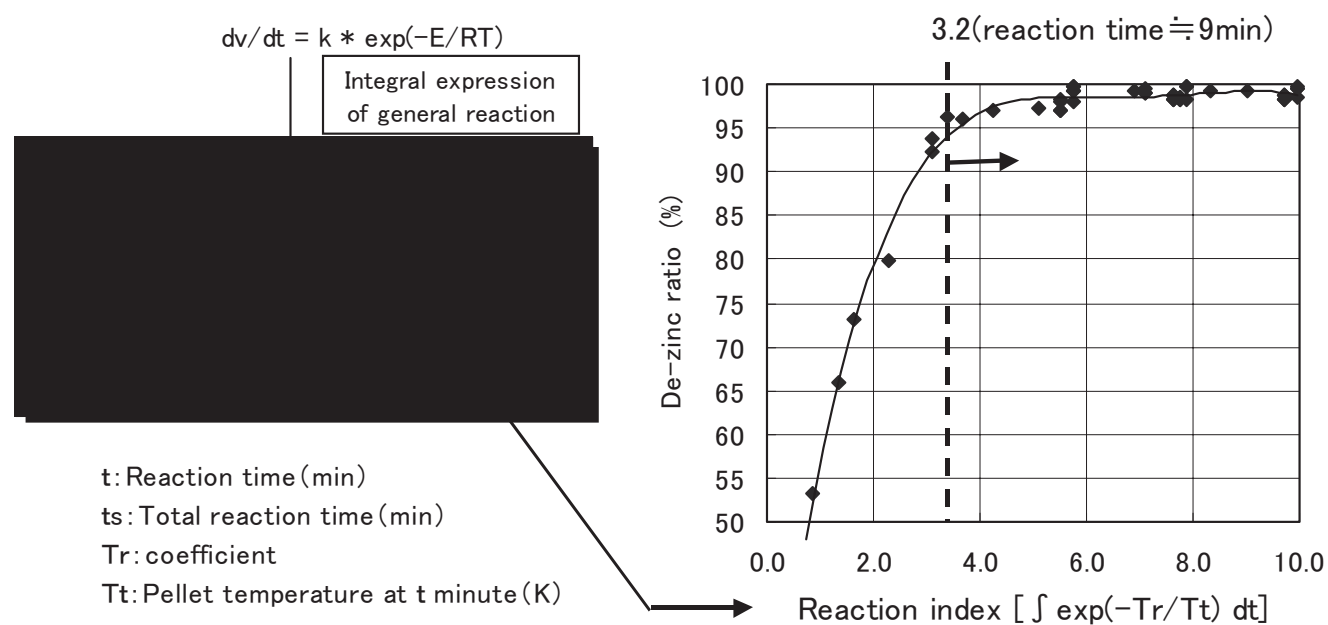

Fig. 4 Relationship between reaction index and de-zinc ratio

検討を入念に行った。

ダスト配合条件及び還元条件を種々調整した実験を行い 詳細に検討した結果、高炉装入に耐え得る高強度を有する 還元ペレットの製造が可能であることを見出し、高炉原料 としての再資源化に踏み切った。回転炉床法による処理製 品の高炉原料としての直接使用は世界初の技術である。

\subsection{RHF 炉内反応処理条件の最適化}

回転炉床での還元脱亜鉛処理において、処理後製品の反 応率及び強度を確保し得る最低限の反応温度・時間につい て、検討を詳細に実施した。実験炉において昇温中のペレッ トの温度履歴を測定し、温度の時間積分形である反応指標 の式を作成した。この反応指標と反応率（脱覀鉛率等）と の関係を解析した結果、目標の反応率に達する最低限の反 応指標が求められることを確認した。この所定の反応指標 となる最適な反応温度及び時間にてダスト処理することに より、最小のエネルギーにて望ましい還元製品性状が得ら れる技術を確立した（Fig. 4)。

\subsection{RHF に供給するダスト事前処理技術の開発}

この RHFのダスト処理による高品質還元製品製造の重要 技術の一つとして、ダストの事前処理における RHF 投入成 形体性状の適性化が挙げられる。

対象原料のダスト、スラジ類は、粒子径としてはサブミ クロンから数ミリ程度、水分としては 0 から $98 \%$ という広 範囲のものであり、これら広範囲の物性に対する適正な処 理が必要となる。さらに各ダス卜銘柄においても、その性 状が発生元の操業状況により変化するものであり、これを 原料として量及び質の安定した成形体を供給することは、 検討当初より最重要課題として開発に取り組んできた。

この結果、重点技術項目として、(1)成形性に優れた基本 配合パターンの確定 (2)各ダストの日常的な性状及び発生

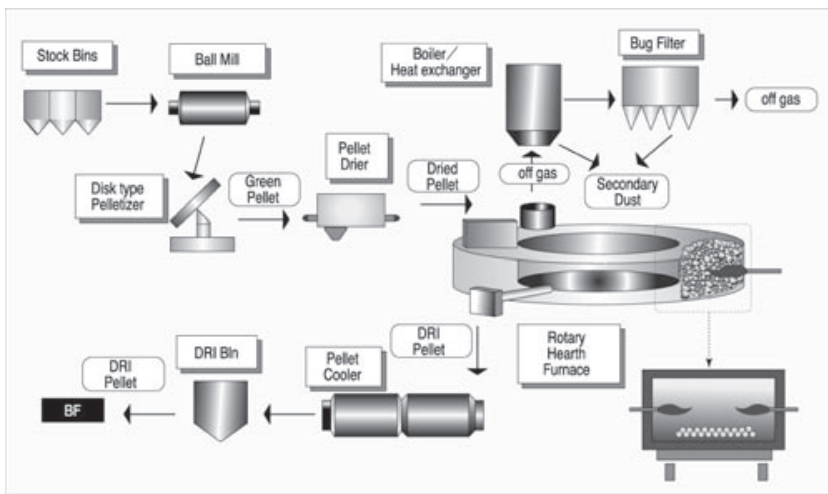

Fig. 5 Flowchart of No.1 plant

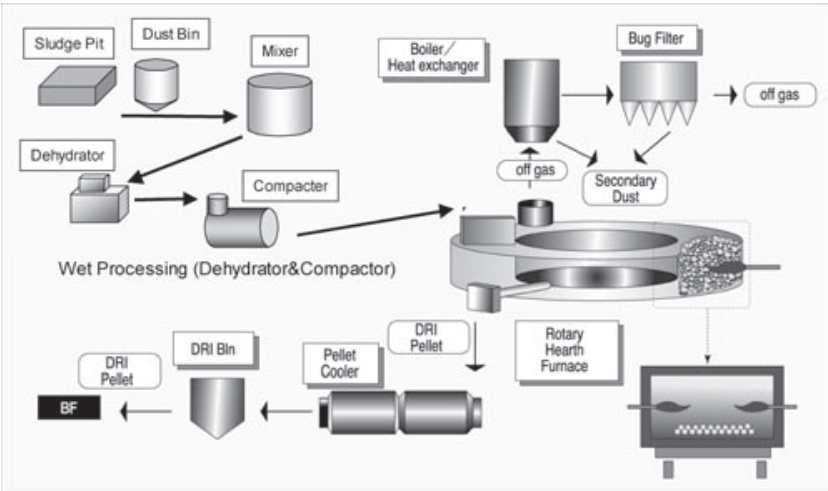

Fig. 6 Flowchart of No.2 plant

量変動に応じた配合の最適調整要領の構築 を達成し、最 適基本配合及び配合調整要領を確立した。

\section{5. ダストリサイクル設備の概要}


Table 2 Specification of the plants

\begin{tabular}{|c|c|c|}
\hline & No.1 RHF & No.2 RHF \\
\hline Agglomerate & $\begin{array}{c}\text { Pellet } \\
\text { (Disc Pelletizer) }\end{array}$ & $\begin{array}{l}\text { Wet Processing } \\
\text { (Compactor) }\end{array}$ \\
\hline $\begin{array}{l}\text { Hearth Diameter } \\
\text { (at Hearth Center) }\end{array}$ & $20 \mathrm{~m}$ & $20 \mathrm{~m}$ \\
\hline Hearth Area & $230 \mathrm{~m}^{2}$ & $230 \mathrm{~m}^{2}$ \\
\hline $\begin{array}{c}\text { Processing Capacity } \\
\text { (Green Pellet Base(dry)) }\end{array}$ & $\begin{array}{c}22 \mathrm{t} / \mathrm{h} \\
15,000 \mathrm{t} / \mathrm{M}\end{array}$ & $\begin{array}{c}17 \mathrm{t} / \mathrm{h} \\
10,000 \mathrm{t} / \mathrm{M}\end{array}$ \\
\hline Green Pellet Diameter & $5-20 \mathrm{~mm}$ & $5-30 \mathrm{~mm}$ \\
\hline $\begin{array}{c}\text { Processing Temp. } \\
\text { Retain Time }\end{array}$ & $\begin{array}{c}1,250-1,300{ }^{\circ} \mathrm{C} \\
10-20 \mathrm{~min} \\
\end{array}$ & $\begin{array}{c}1,250-1,300{ }^{\circ} \mathrm{C} \\
15-30 \mathrm{~min} \\
\end{array}$ \\
\hline Off-gas System & $\begin{array}{c}\text { Boiler, Air heater, } \\
\text { Bag house }\end{array}$ & $\begin{array}{c}\text { Boiler, Air heater, } \\
\text { Bag house }\end{array}$ \\
\hline
\end{tabular}

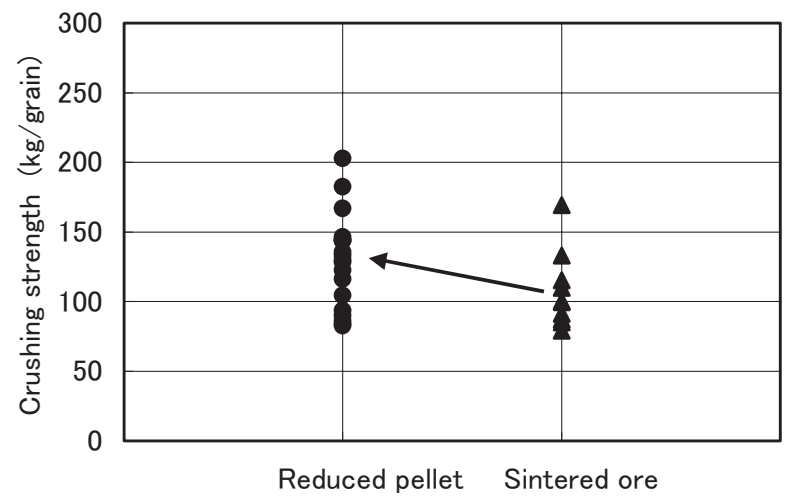

Fig. 7 Crushing strength of reduced pellet

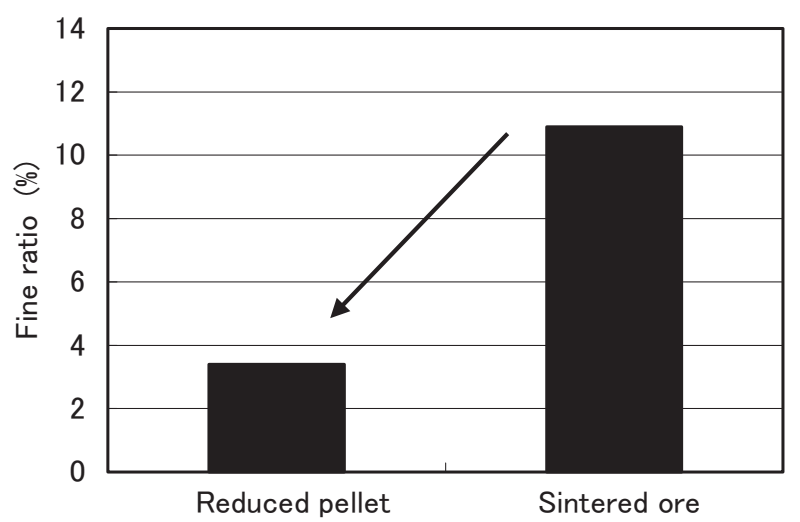

Fig. $8-5 \mathrm{~mm}$ fine ratio in rotary strength test
今回導入した、RHFによる 2 基のダストリサイクル設備 のプロセスフローを Fig. 5、6に示す。

また、Table 2 にそれぞれの設備の主仕様を示す。

No.1 設備では、事前処理装置としてディスク型のペレタ イザーを使用している。

各ホッパーに貯蔵されたダスト銘柄を所定の配合で切出 し、ボールミルで混合、ディスク型のペレタイザーで生 ペレットを製造する。この生ペレットを事前乾燥した後、 RHF へ投入する。

No.2 設備では、スラリー配管輸送およびバキューム、ト ラック等で搬入されたスラジ類主体の原料を各ピットにて 一旦貯留する。各スラジを混合槽で所定割合に混合し、脱 水機にて脱水、押出し成形機にて生ペレットを成形した後、 RHF に投入する。

RHFを 1 周して還元脱亜鉛されたペレットは冷却し製品 ホッパーに貯留し高炉へと輸送する。

亜鉛を含む排ガスはボイラー、レキュペレータにて熱交
換した後、集塵機にて亜鉛の濃縮した 2 次ダストを捕集す る。

\section{6. 還元製品性状}

高炉での一般的な原料である焼結鉱との強度比較を Fig. 7、8に示す。

特に回転磨耗試験において粉率の極めて低い高品質のも のが得られていることが判る

還元ペレットの外観、及び断面写真を Fig. 9 に示す。還 元ペレットが緻密な金属化により高い強度を有しているこ とが判る。

\section{7. 高炉での還元ペレット使用効果}

前述のような性状の還元ペレットの高炉使用により、高 炉側の効果として以下のような効果が期待される。

・還元製品使用による高炉還元材比低減 ・ダスト鉄源使用による主原料原単位低減 


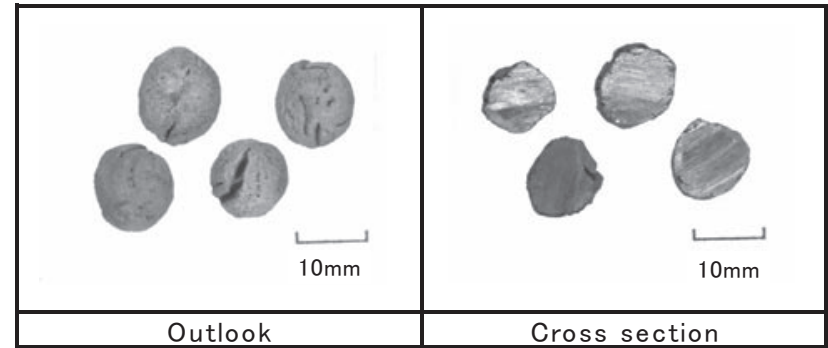

Fig. 9 Outlook and cross section of reduced pellet

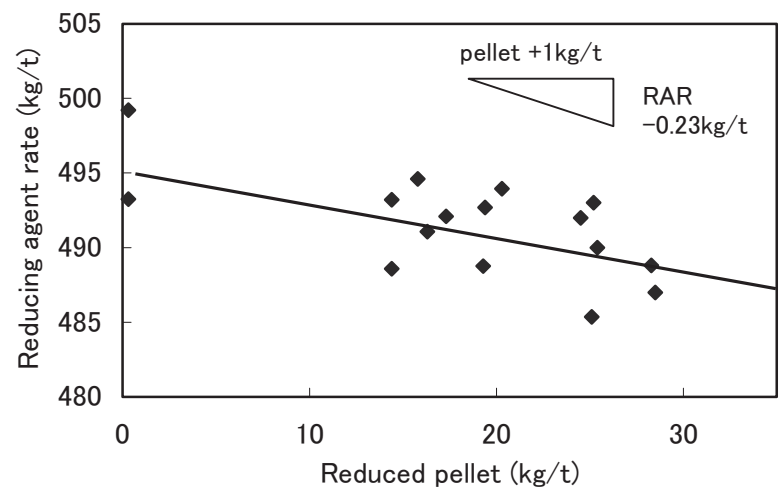

Fig. 10 Relationship between reduced pellets ratio and reducing agent rate in the blast

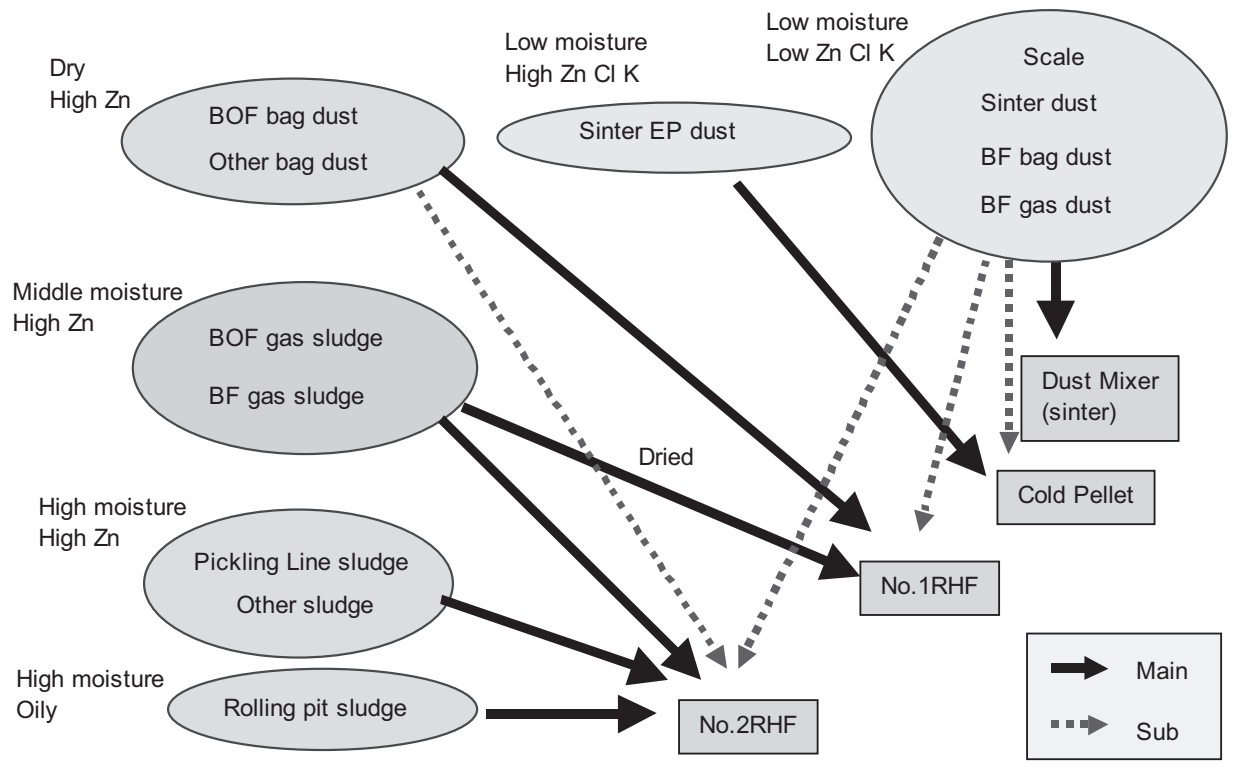

Fig. 11 Material flow of dust and sludge in Kimitsu Works

・高強度ペレット使用による高炉操業改善

高炉での還元製品使用原単位と高炉還元材比との関係を 解析した結果を Fig. 10 に示す。

高炉での還元ペレット $30 \mathrm{~kg}$ 装入につき約 $7 \mathrm{~kg}$ の還元材比 低減効果となっており、高炉操業改善効果により、還元エ ネルギー相当分以上の還元材比低減効果が得られているこ とが確認された。

なお、今回のダストの再資源化による炭素分、鉄分の有 効利用等により年間総計 $1400 \mathrm{TJ}$ 、原油換算で約 3 万 5 千キ ロリットルの省エネルギー効果を得た。

\section{RHF を適用したダストリサイクルシステム}

今回のダスト再資源化のトータルシステムにおけるダス トの分配について Fig. 11 に示す。
まず、低水分かつ亜鉛や塩素、アルカリの低いダストと して、スケール、焼結ダスト、高炉環境集塵ダスト及び若 干亜鉛の高い高炉ガス灰があり、これらは、焼結にて使用 している。

次に、水分や亜鉛は低いが、塩素、アルカリ等の若干高 いものとして焼結の電気集塵ダストがある。これは焼結に は戻せないためコールドペレットとして高炉にて使用して いる。

さらに、高亜鉛で乾燥品または低水分であるものとして、 転炉環境集塵ダストや転炉スラジ、高炉シックナー灰の脱 水品があり、これらについては、脱亜鉛機能を有する No.1 RHF 設備で使用している。

最後に、水分の高い未脱水の高炉シックナー灰や転炉、 圧延等での浚渫スラジ等については、No.2 RHF 設備にて処 
理している。

このようにダスト性状に合わせた各処理工程への最適な 分配を行うと共に、各ダストの補間的使用も含め、適宜最 適な分配を行うことで、多種多様なダスト・スラジ類の再 資源化を達成した。

\section{9. 結言}

君津製鐵所において RHF 設備を 2 基設置し、現在順調に 稼働しており、さらに 3 基目も 2008 年に稼動予定である。

RHF 設備の適用において、ダスト原料の造粒・成形、反 応条件制御、排ガス処理等の安定操業技術の確立および、 高炉用の高強度還元ペレット製造技術を確立し、RHFでは 世界初の高炉での再資源化に成功した。このような、RHF、 コールドペレット等の組み合わせを行うことにより、製 鐵所にて多種多様に発生する全てのダスト、スラジ類の再
資源化を可能とする新たなダストリサイクルシステムを構 築した。現在、海外にも本技術による RHF ダス卜再資源化 設備の適用が広がりつつあり、今後さらに世界的な省資源、 省エネルギーに展開していきたい。

\section{引用文献}

1）高橋政治、織田博史、茨城哲治、大塚一、高島俊治、野々山誠二: “君津ダストリサイクルプロセスの設備と操業”、CAMP-ISIJ. 14, (149) 2001

2）織田博史．茨城哲治．高橋政治：“回転炉床法によるダストリ サイクル技術”、新日鐵技法、第 376 号、平成 14 年 3 月、p. 28

3）織田博史、茨城哲治: “RHFによる高水分スラジ再資源化設備”、 CAMP-ISIJ. 17, (857) 2004

4）織田博史, 茨城哲治：“君津製鐵所での新ダストリサイクルシ ステムの構築”、CAMP-ISIJ. 17,（856）2004 